\title{
The Planning-Implementation-Reporting Gap of the Regional Development Accountability in Indonesia from Principal-Agent Theory
}

\author{
Muhammad Faried Wajdy ${ }^{1}$, Hardi Warsono ${ }^{2}$, Widiartanto ${ }^{3}$, Teguh Yuwono ${ }^{4}$, Setyo \\ Atdiwaluyo $^{5}$ \\ \{hardie_wsn@live.undip.ac.id $\left.{ }^{2}\right\}$ \\ Universitas Diponegoro, Indonesia ${ }^{1,2,3,4}$ \\ Regional Research and Development Planning Board of Tegal Regency, \\ Central Java Province, Indonesia ${ }^{5}$
}

\begin{abstract}
This research analyzes the dynamics of regional planning process in the framework of principal-agent theory. The primary purpose of public sector reform is a successfully implemented public accountability. In order to achieve the purpose, planning policy formulation plays a crucial role in a public institution. At the regional level, development planning is a process-oriented activity that exerts technocratic, political, participatory, top-down, and bottom-up approaches. However, moral hazard may occur in the planning process owing to information asymmetry. This paper identifies the actors involved in regional development planning, each of whom plays a role as a trustee (principal) and recipient of the mandate (agent). The output of principal-agent relationship mapping indicates that information asymmetry still prevails. The absence of reporting procedure and agent-to-principal liability mechanism demonstrates that the accountability of regional development planning has not been well conceptualized.
\end{abstract}

Keywords: Accountability, Development Planning, Principal-Agent

\section{Introduction}

The development planning mechanism at both the central and regional levels is regulated explicitly in Law Number 25 of 2004 concerning the National Development Planning System, which aims to integrate development planning into a comprehensive and integrated planning system, starting from the central government to regional governments. The law mandates the government to formulate a Long-Term Development Plan (RPJP), which contains twenty years of policies. And the Medium-Term Development Plan (RPJM) as a development plan for five years and the Government Work Plan (RKP) as an annual development plan for both the Central and Local Governments. The objectives of development planning are (i) to support coordination among development actors; (ii) ensuring the creation of integration, synchronization, and synergy between regions, between spaces, between time, between government functions, and between the central and regional governments; (iii) ensuring linkages and consistency between planning, budgeting, implementation and supervision; (iv) maximizing community participation; and (v) ensuring the achievement of efficient, effective, equitable and sustainable use of resources. 
Planning process has a significant role in the process of achieving regional development goals. Regional development planning is a deliberate effort to empower and increase the community's capacity and the potential of the region to improve community welfare. Efforts to improve community welfare are carried out through a series of policy formulations for regional development planning from various aspects, including economic, social, cultural, infrastructure, and other aspects.

The principles of the formulation of Regional Development Planning policies as contained in Government Regulation Number 8 of 2008 concerning the Stages, Procedures for the Preparation, Control, and Evaluation of the Implementation of the Regional Development Plans are 1) It is an integral part of the national development planning system; 2) Conducted by local governments together with stakeholders based on their respective roles and authorities; 3 ) Integrate spatial plans with regional development plans; and 4) Implemented based on the conditions and potential of each region, according to the dynamics of regional, national and global developments.

The formulation of process-oriented regional development planning policies is stipulated in the Minister of Home Affairs Regulation Number 86 of 2017 concerning Procedures for Planning, Control, and Evaluation of Regional Development, Procedures for Evaluating Draft Regional Regulations concerning Long-Term Regional Development Plans and Regional Medium-Term Development Plans, Procedures for Changing Regional Long-Term Development Plans, Regional Medium-Term Development Plans, and Regional Government Work Plans. The approach used in the process orientation framework are technocratic, participatory, political, and top-down and bottom-up. The technocratic approach is implemented using scientific methods and frameworks to achieve regional development goals and objectives. A participatory approach is carried out by involving various stakeholders. The political approach is carried out by translating the vision and mission of the elected regional head into a medium-term development planning document discussed with the DPRD. The top-down and bottom-up approaches result from planning that is harmonized in development deliberations that are carried out from villages, sub-districts, regency/municipalities, provincial to national regions.

Accountability is a prerequisite for increasing the capacity of the development planning system. Various parties conveyed the importance of accountability for the planning process on various occasions. At the launch of the Third Generation KRISNA application (KRISNA 3.0), the Minister for State Apparatus Empowerment and Bureaucratic Reform (Menpan RB) stated that the planning, budgeting, and performance information system were the three main foundations for overseeing the implementation of the state budget in an accountable manner. The Minister of National Development Planning/Head of Bappenas supports all planning, budgeting, implementation, monitoring, and evaluation processes up to auditing and feedback, with an emphasize for the planning process to be carried out in an integrated, transparent, accountable, and paperless manner (Kemenpan RB, 2019).

As mentioned above, there are five aspects in the planning process: top-down, bottom-up, participation, technocracy, and politics. Unfortunately, the reality differs from the expected condition according to the Minister of Home Affairs Regulation Number 86 of 2017. The topdown process transfer funds from the center to the regions has been regulated, while the bottom up, so far, is only a formality because the participation process in development planning deliberations does not take place in a negotiation process, but only dissemination and delivery of public information. Communities and interest group groups have not been actively involved in planning optimally from the start and are only given information on the results of the planned 
planning. The wider community's desire to participate in supervising this process has always hampered the accessibility of information and data [1].

Based on the above description, there is a common thread that requires an in-depth examination, namely the relationship between the process-oriented planning stages and efforts to fulfill accountability by agents to principals. In this paper, a theoretical and practical study will be carried out on the dynamics of implementing accountability by agents to principals in each of the technocratic, political, participatory, and top-down and bottom-up planning approaches. The expected result is an increase in conceptual discourse about planning accountability in terms of principal-agent theory.

\section{Methods}

This research used a qualitative method analyses Creswell [2] and Yin [3] to analyze the dynamics in the policymaking process. The information was mainly obtained from direct involvement in the planning stages, supported by literature and regulation exploration. Actor analyses Birkland [4] and Considine [5] was conducted to understand each actor roles and interests.

\section{Results and Discussion}

\subsection{Public Accountability and Principal-Agent Theory}

Bastian [6] defines public accountability as a form of performance accountability that must be made to be explained to those who have the authority to accept it. Meanwhile, according to Nordiawan [7], public accountability is reported periodically for implementing policy and resource management. A similar opinion is from Mursyidi [8] that public accountability is responsible for managing resources and implementing policies entrusted to the reporting entity to achieve the objectives set periodically. Based on these three opinions, it can be concluded that accountability for government agencies' performance is in the form of periodic reporting to be accountable for their activities to the public.

The definition of public accountability with a different emphasis, as Halim [9] argues, is the obligation to convey accountability with an explanation of the performance of a person, legal entity, or organization leader to other parties who have the right and obligation to hold accountability. Meanwhile, according to Mahmudi [10], public accountability is the obligation of the recipient of the mandate, namely the agent, the government, to submit reports on all public resource management activities to the mandate or principal. A relatively similar opinion is conveyed by Mardiasmo [11], which states that public accountability is the obligation of the trustee or agent to provide accountability in the form of presenting reports on all activities that are the responsibility of the trustee or principal who has the right and authority to request the accountability. These three opinions emphasize the existence of two parties involved in a concept of public accountability, namely the principal as the party giving responsibility and the agent as the party implementing and conveying accountability.

According to Ulum [12], there are two types of accountability: internal accountability and external accountability. Internal accountability applies to every government organization level, where every government apparatus is obliged to account for its performance to its superiors 
periodically. External accountability is attached to every government agency as an organization to convey accountability for a mandate received and implemented to external parties and the environment.

Wasistiono [13] suggests five perspectives of accountability: a. Administrative/organizational accountability, accountability between authorized officials and subordinate units in a clear hierarchical relationship. b. Legal accountability, this type of accountability, refers to the public's dominance associated with the legislative and judicial processes. c. In this type, political accountability is related to the authority of the holders of political power to regulate, prioritize, and distribute resources and ensure compliance in carrying out administrative and legal responsibilities. d. Professional accountability relates to implementing performance and actions based on benchmarks set by similar professions. e. Moral Accountability, this accountability is related to the overall values in society.

According to Mahmudi [10], public accountability consists of two types, namely: Vertical Accountability, which is accountability conveyed to a higher authority, and Horizontal Accountability, which is accountability to the public at large or to other institutions that have no superior, subordinate relationship. Mardiasmo [11] also divides two types of Public Accountability, consisting of Vertical Accountability and Horizontal Accountability. Vertical accountability is defined as the delivery of accountability for resource management to a higher authority, whereas Horizontal Accountability is responsible for managing resources to the public. Public sector reform, among others, mandates the realization of public accountability, which obliges public sector institutions to emphasize more on horizontal accountability to the public, not just vertical accountability to the institutions above it.

Public accountability from several of the above meanings provides a discourse on the importance of the roles of those who make, report, and accept accountability. The identification of parties referred to as principals (mandates) and agents (mandate recipients) in the context of public accountability in the preparation of regional development planning is an exciting matter for review.

Principal-agent theory, also known as agency theory, explains the relationship between principal and agent. According to Lane [14], analyze public policy commitments, there is a series of principal and agent relationships to apply agency theory. The principal-agent approach has been started since the 1970s to understand the interactions between company owners and employees in private sector organizations. Furthermore, this approach has developed to be used in the public sector to understand public sector organizations' problems, particularly the behavior of bureaucrats. The main idea of the principal-agent theory or agency theory is the formation of organizations that work efficiently and effectively by examining the performance accountability relationship between principals and agents.

According to Lipia (2001) in Wijaya [15], the principal-agent theory application represents the delegation of something from the principal to the agent who gets the delegation. Delegation is stated to occur when the agent has carried out a job per the party's wishes giving the delegation. In the public sector, according to the thoughts of Tullock [16], Downs [17] or Niskanen [18], state that the bureaucracy only thinks about itself by storing information for the sake of alone and there is a tendency to neglect the performance of duties. Principal-agent theory explains the principal-agent relationship between political authority and bureaucracy. The control relationship between superiors and subordinates in the bureaucracy itself with the basic premise of information gaps and the difficulty of controlling the bureaucracy.

Eisenhardt [19] states that agency theory uses three assumptions of human nature: humans are generally selfish, humans have limited thinking power about future perceptions, and human tendencies always avoid risk. Information regarding personal capacity, work environment, and 
the company is owned by the agent, while the principal does not have sufficient information about the agent's performance. When the principal does not know many situations, it will result in policy considerations and the achievement of unrealized goals due to an imbalance of information held by the principal and the agent; this condition is called information asymmetry.

The study in planning accountability in this paper will review from the point of view how reporting and accountability are carried out by agents (mandate recipients) to principals (mandates) in each process of technocratic, political, participatory, top-down, and bottom-up planning approaches. Identification of the relationship between principals and agents will also be seen through the types and perspectives of public accountability in each planning approach process. Analysis of principal-agent relationships related to planning accountability provides an overview and finds an imbalance of information that results in the sub-optimal formulation of development planning policies in the regions.

Identifying the principal-agents in the planning process is crucial to know the actors involved in the policy formulation stage. In Wahab [20], Charles O. Jones broadly divides the actors involved in the policy formulation process into two, namely actors within government, the executive and legislative branches. Moreover, actors outside the government consist of community organizations, private, non-profit organizations, organizations, or institutions that provide public services. Meanwhile, Winarno [21] divides the actors in the formulation of public policies into two, namely actors and officially consisting of government, executive, legislative and judicial agents, and actors and informal actors, namely interest groups, political parties, and individual citizens.

Planning policy formulation using a technocratic, political, participatory, and top-down and bottom-up approach involves many parties. The results of the mapping of actors involved include the Central Government such as the Ministry of Home Affairs, Bappenas, the Ministry of Administrative Reform and Bureaucratic Reform; Provincial government; Regency/City Government, Bappeda and Regional Apparatus in Province/Regency/City, Village Government, Private, and Community. These actors in the planning process with various approaches are positioned as mandates (principals) and recipients of mandates (agents) who have to report and be responsible for the mandates.

\subsection{Principal-Agent in a Technocratic Approach}

Law Number 25 of 2004 concerning the National Planning System, in its explanation, states that the technocratic approach is implemented using scientific methods and frameworks by an institution or work unit that is functionally tasked with it. Minister of Home Affairs Regulation Number 86 of 2017 concerning Procedures for Planning, Control, and Evaluation of Regional Development, Procedures for Evaluating Draft Regional Regulations concerning Regional Long-Term Development Plans and Regional Medium-Term Development Plans, also Procedures for Changing Regional Long-Term Development Plans, Plans Regional MediumTerm Development and Regional Government Work Plans stipulate a technocratic approach in regional development planning is implemented using scientific methods and frameworks to achieve regional development goals and objectives.

The technocratic approach deals with professionalism and expertise in the preparation of regional development planning. Planning regional development needs to consider various aspects and expertise so that the results obtained can solve the problems faced by the region comprehensively. Activities carried out at the technocratic stage include analyzing an overview of regional conditions, preparing regional financial figures, identifying regional development problems, reviewing other planning documents, and formulating regional strategic issues. 
Technocratically, studies are also carried out on the Central Government's various policy contents to be integrated into planning documents.

The Central Government, through several Ministries, has a mandate in the form of a policy content that must be technocratically assessed so that it can be internalized in the regional medium-term planning document, as shown above. The technocratic approach taken by the Regional Government in formulating regional development planning policies must be guided by the Minister of Home Affairs Regulation Number 86 of 2017. The Ministry of National Development Planning/Bappenas also provides a mandate to integrate national policy directions and priorities and Sustainable Development Goals (SDGs) in districts' medium-term planning documents. The Ministry of Environment requested the Integration of Strategic Environmental Assessment (KLHS) to be drafted technocratically and taken into consideration to formulate regional development policies and programs. The Ministry of Agrarian Affairs and Spatial Planning provides directions for guiding the Regional Spatial Plan to prepare regional mediumterm planning documents. The formulation of Main Performance Indicators through a technocratic assessment is compiled by employing a cascading method, which is the mandate of the Ministry of Administrative Reform and Bureaucratic Reform. Furthermore, each sectoral Ministry mandates the integration of Minimum Service Standards (SPM) to calculate the planning documents' target performance indicators.

The various Ministries that give mandates in the technocratic planning policy formulation are the principals and the Local Government who have the mandate as agents. To fulfill the concept of public accountability, it is the duty of the trustee (agent) to provide accountability, present, report, and disclose all activities and activities of technocratic planning policy formulation, which are the responsibility of the trustee (principal) who has the right and authority to ask the accountability. The real condition that occurs is that agents do not deliver reporting and accountability for technocratic planning by agents to principals. A technocratic planning approach whose processes are reported and accountable not directly to the Ministry but through a facilitation and evaluation mechanism carried out by the Directorate General of Regional Development of the Ministry of Home Affairs for planning at the provincial level and the Provincial Regional Development Planning Agency for planning at the District/City level. There is no instrument specifically made for the existence of a planning accountability mechanism for the agency's technocratic process, in this case, the Regional Government, to each Ministry as the principal who has given the mandate.

Under these conditions, there is an imbalance of information asymmetry between the principal, namely the Ministry with various mandates in the form of policy contents in the planning document, and the Regional Government that carries out the technocratic planning process. Principals do not get adequate information because there is no reporting mechanism and accountability for the technocratic planning process per the mandated policy content. Meanwhile, the agency has information on the technocratic planning process that has been carried out related to the policy content that has been integrated into the planning document.

\subsection{Principal-Agent in a Political Approach}

According to Law Number 25 of 2004 concerning the National Planning System, the political approach views that the election of the President/Regional Head is a process planning because the voters determine their choice based on the development programs offered by each candidate for President/Regional Head. Therefore, the development plan elaborates on the development agendas offered by the President/Regional Head during the campaign into the medium-term development plan. Meanwhile, Minister of Home Affairs Regulation Number 86 
of 2017 regulates that the formulation of a political approach planning policy is carried out by translating the vision and mission of the elected regional head into a medium-term development planning document discussed with the DPRD.

Before the candidates for Regional Head compete in the General Election, there are stages to convey the vision and mission of the campaign to the prospective voters. The vision and mission material prepared by the candidates for Regional Head refers to the Technocratic RPJMD Draft, so it is hoped that there will be continuity of development policies in the regions guided by the RPJPD. The formulation of regional development planning policies with a political approach makes the elected regional head's vision and mission as the primary reference that is then translated into goals, objectives, strategies, policy directions, and the formulation of regional development programs and target indicators. The Regional Development Planning Agency (Bappeda) is the institution entrusted with its primary duties and functions are to compile the Draft RPJMD.

Identification of the principal-agent in this political planning approach The Regional Head is elected as the principal with the vision and mission to be translated into a regional mediumterm development planning document by Bappeda as the agent. At the latest, in six months since the Regional Head is inaugurated, the RPJMD document must be agreed upon with the Regional People's Representative Council (DPRD) and stipulated in a Regional Regulation. During the period of formulation of the regional development planning policy, intensive communication was established between the Head of the Region and the Regional Development Planning Agency (Bappeda) to be able to translate the vision and mission goals and objectives up to the program and the determination of its performance indicators.

There should be no obstacles in planning accountability in a political approach if intensive communication is established through discussions between the Head of the Region and Bappeda and other Regional Apparatus in translating the vision and mission into a regional medium-term development planning document. Submission of reports and accountability for translating the vision and mission in the RPJMD document is submitted periodically during discussions between principals and agents. Before the draft RPJMD is submitted to the DPRD for discussion, there is a mechanism for submitting the final draft RPJMD by the Head of Bappeda to the Regional Head to obtain notes on improvements and feedback from the Regional Head.

Information asymmetry does not occur if the two-way communication and discussion process go well between the Regional Head and Bappeda and other Regional Apparatus in formulating development programs and target indicators to achieve the Vision and Mission. The type of accountability for planning this political approach is internal accountability. It applies to every level in the internal organization of state administration. Every public official/officer, both individuals/groups, is obliged to be accountable to their superiors regarding the performance development/results of implementing their activities periodically or at any time if deemed necessary.

\subsection{Principal-Agent in a Participatory Approach}

According to the explanation of Law Number 25 of 2004 concerning the National Planning System, planning with a participatory approach is carried out by involving all interested parties (stakeholders) in development. Their involvement is to get aspirations and create a sense of belonging. Meanwhile, the Minister of Home Affairs Regulation Number 86 of 2017 regulates that a participatory approach is implemented by involving various stakeholders.

The term participation is taken from a foreign language, namely participation, which means including other parties. The opinion of Mubyarto [22] defines participation as a 
willingness to help each program's success according to the ability of each person without sacrificing one's interests. Heroepoetri [23] defines participation as feed-forward information and feedback information. By this definition, community participation as a continuous two-way communication process means that community participation is communication between the government as the policyholder and the community, as the party who feels the policy's impact directly. As for Participatory Development Planning, according to Abe [24], participatory planning that involves the community will have a significant impact in development, namely: avoiding opportunities for manipulation, providing added value to the legitimacy of planning formulations, and increasing public awareness and political skills.

The participation space formed in the regional development planning process per the Minister of Home Affairs Regulation Number 86 of 2017 is the holding of development planning deliberations and regional apparatus forums attended by all stakeholders. The presence of stakeholders in the deliberation forum is expected to provide input in the form of suggestions and information on problems and potentials related to regional development plans. In the participatory planning process, the principal is community groups, communities, and all stakeholders related to Local Government policies. The stakeholder's position provides the mandate in the form of suggestions and input and various information to be accepted by the Regional Government, which is an agent who, in the principle of accountability, must submit an accountability report to the principal.

The development planning deliberation forum and the Regional Apparatus Forum are held formally to obtain input and activity proposals from stakeholders on the planning policy draft submitted at the activity. The formality of the regional apparatus forum activities is more due to the absence of an obligation from the agent to report and to account for the principal (stakeholder). There is no mechanism specifically regulated to serve as a vehicle for submitting accountability reports for proposals submitted to stakeholders by the Regional Government or respective Regional Apparatus. The position of stakeholders as principals is only positioned as conveyors of proposals. It is not interpreted as a mandate that is entrusted to the agent to be fulfilled and implemented.

There is an imbalance of information (information asymmetries) between the principals, namely the stakeholders with various mandates in the form of input suggestions and activity proposals submitted at development deliberation forums and regional apparatus forums. Principals do not get adequate information because there is no reporting mechanism and accountability for the participatory planning process to know the accommodation process for suggestions and input and proposed activities. Meanwhile, agents have much information on the participatory planning process that has been carried out concerning how many proposed activities can be accommodated in the planning document.

\subsection{Principal-Agent in a Top-Down and Bottom-Up Approach}

According to the explanation of Law Number 25 of 2004 concerning the National Planning System, planning with a top-down and bottom-up approach is carried out according to the level of government. The top-down and bottom-up process results from plans are aligned through deliberations held at the national, provincial, district/city, sub-district, and village levels. As Minister of Home Affairs Number 86 of 2017 Regulation mandates, Top-Down and Bottom-up approach results from planning that is harmonized in development deliberations carried out starting from villages, sub-districts, regency/city, provincial, to national.

Top-down and bottom-up approaches in the planning framework regional development, then regional development planning is related to national development. Therefore, regional 
development planning, in addition to describing local interests, is also an elaboration of central (national) planning. According to Abe [24], there are two types of regional planning: 1 . Regional planning as a form of planning (development); an implementation or elaboration of central (national) planning. In this case, two possibilities can occur, namely (1) regional planning is part of central planning and (2) regional planning is an explanation of the national plan that is carried out in the regions. The preparation process can be done through top-down or bottom-up. 2. Regional planning as a result of regional struggles in formulating local interests. In this matter, there are two possibilities: (1) regional planning as a pure formulation of regional interests without considering the corridor from the center, and (2) regional planning is nothing more than an opportunity given by the central government to be filled by the regions.

The definition of regional planning explains the national plan that is carried out in the region, which means the Top-Bottom planning approach. The Central Government conveys the policy directions and national development priorities through the National Long-Term Development Plan (RPJPN) document as a guideline for the preparation of the Regional LongTerm Development Plan (RPJPD), the National Medium-Term Development Plan (RPJMN) as a guideline for preparing the Regional Medium-Term Development Plan (RPJMD) and Government Work Plans (RKP) as guidelines for the preparation of Regional Government Work Plans (RKPD). The bottom-up planning approach is implemented through a multi-level development planning deliberation forum (Musrenbang). Starting from the village level Musrenbang, subdistrict level Musrenbang, district-level Musrenbang, city-level Musrenbang, Provincial level Musrenbang and National level Musrenbang. The proposed development plan from the Village level is submitted in stages so that it can be accommodated by the level of government above it per their respective authorities.

Top-down and Bottom-up approaches can be explained through the annual development planning cycle. At the beginning of each year, the Central Government and Provincial Governments convey policy directions and development priorities that must become Regional guidelines when formulating annual planning policies. It is a form of top-down planning approach. Furthermore, the Bottom-up process starts with the Village level Musrenbang held in January. The Sub-District Musrenbang in February, then the Regency/City Musrenbang in March, the Provincial Level Musrenbang in April, and the National Musrenbang held in May. After the Musrenbang stages have been fully implemented, the Top-down process begins again with the Government Work Plan's stipulation in June. It is then guided in determining the Provincial Government Work Plan and then used as a reference for determining the Work Plan for the Regency/City Government.

Identify principals and agents into a unique pattern in the Top-down and Bottom-Top planning approach. In the Top-Under-Government approach above, it becomes the principal, and the government under it becomes the agent. The Provincial Government becomes the agent of the Central Government, but at the same time becomes the principal for the Regency/City Government and the Village Government. On the other hand, in the bottom-up planning approach, the government at the lowest level (representing the people in their jurisdiction) becomes the principal for the government above it. The Regency/City Government becomes the agent for the Village Government but, at the same time, becomes the principal for the Provincial Government and the Central Government. The position of the Provincial Government is to become the agent of the Regency/City Government and the Village Government, as well as being the principal for the Central Government.

The principal-agent relationship in the top-down and bottom-up approach occurs in an imbalance of principal and agent information. Information gaps in the top-down approach occur because the government at the above level tends not to receive adequate reporting and 
accountability as a follow-up to or fulfillment of mandated policy directions and development priorities. Likewise, in the bottom-up approach, the government at the lower level as the principal does not get adequate information in reporting and accountability from the agency for various suggestions and suggestions for activities submitted at the Musrenbang forum.

The demand for public accountability requires public sector institutions to emphasize horizontal accountability, not just vertical accountability. Horizontal accountability is accountability to the broader community. The bottom-up approach also represents the community's mandate whose proposals are submitted by the government at a lower level as the principal to obtain complete information related to decisions on proposals.

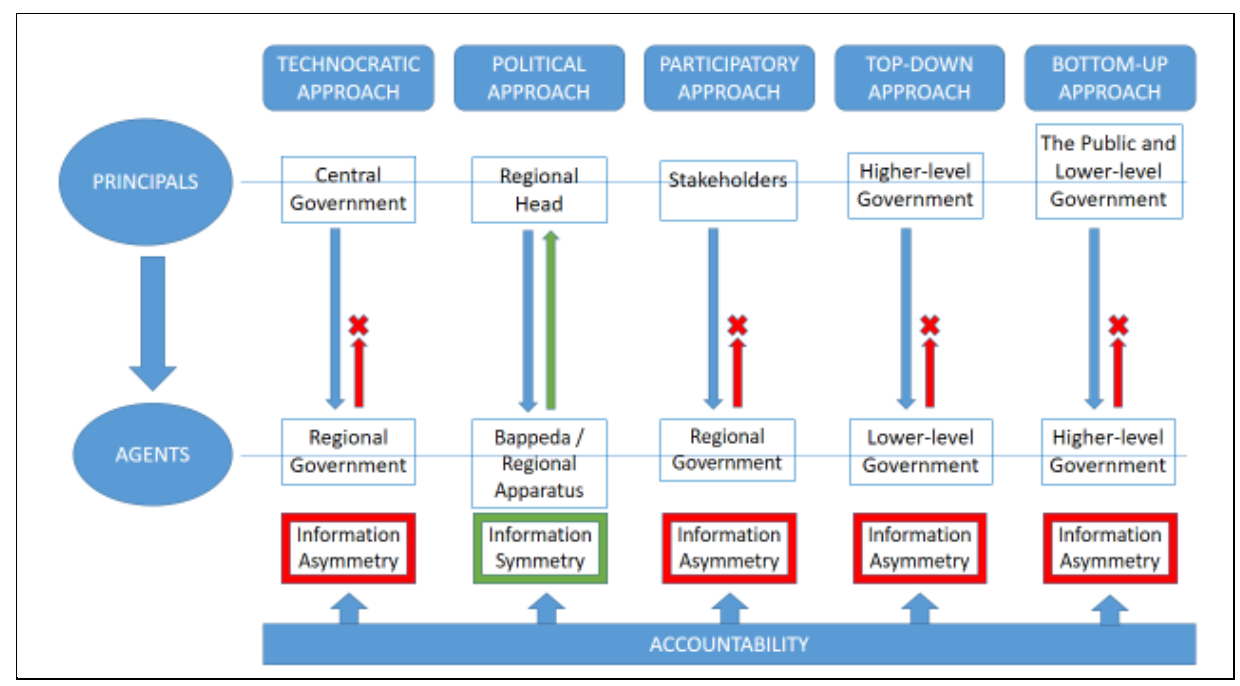

Fig. 1. Planning Process Approaches Review Using Principal-Agent Theory. Source: Author's analysis.

\section{Conclusion}

One of the agendas for public sector reform is to achieve public accountability. The formulation of planning policies is a strategic stage that determines the success of a public organization's goals. Regional development planning is process-oriented through a technocratic, political, participatory, top-down, and bottom-up approach. The results of the identification of actors involved in the regional development planning process have mapped their roles as trustees (principals) or trustees (agents). Public accountability is the trustee (agent) obligation to provide accountability, present, report, and disclose all activities and activities which are their responsibilities to the trustee (principal) who has the right and authority to hold this accountable.

The review of local development planning accountability regarding the relationship between principals and agents concludes several matters. Firstly, planning policies formulation with a technocratic approach has an information asymmetry imbalance. Principals do not get adequate information due to the absence of reporting mechanisms and accountability for the technocratic planning process per mandated policy content. Secondly, the political approach in the planning process is relatively asymmetrical in information, provided there is intensive two- 
way communication and discussion between the Regional Head and Bappeda and other Regional Apparatus in translating development programs and target indicators in order to achieve the Vision and Mission. Thirdly, in the regional development planning with a participatory approach, information asymmetries occur. Principals do not get adequate information because there is no reporting mechanism and accountability for the participatory planning process to determine how accommodated the input suggestions and activity proposals submitted are. Fourthly, in the development planning with a process orientation using the topdown approach, inequality occurs in information because the government at the above level tends not to get adequate reporting and accountability as a follow-up or fulfillment of mandated development policy directions and priorities. Likewise, in the bottom-up approach, the government at the lower level as the principal does not get adequate information in the form of reporting and accountability from the agency for various suggestions and suggestions for activities submitted at the Musrenbang forum.

\section{References}

[1] Seknas Fitra, "Korupsi (sudah) Terjadi Sejak Perencanaan Anggaran,” Seknas Fitra, 2012. [Online]. Available: https://seknasfitra.org/korupsi-sudah-terjadi-sejak-perencanaan-anggaran/.

[2] J. W. Creswell, "Research design pendekatan kualitatif, kuantitatif, dan mixed," Yogyakarta: Pustaka Pelajar, 2010.

[3] R. K. Yin, "Qualitative research from start to finish. 2010.” New York: Guilford Press, 2011.

[4] T. A. Birkland, An introduction to the policy process: Theories, concepts, and models of public policy making. Routledge, 2019.

[5] M. Considine, Making public policy: institutions, actors, strategies. Polity, 2005.

[6] I. Bastian, “Akuntansi sektor publik: Suatu pengantar," Jakarta: Erlangga, vol. 6, 2006.

[7] D. Nordiawan and A. Hertianti, “Akuntansi sektor publik," Jakarta: Salemba Empat, 2006.

[8] Mursyidi, Akuntansi Pemerintahan di Indonesia. Bandung: PT. Refika Aditama, 2013.

[9] A. Halim and S. Kusufi, “Akuntansi Sektor Publik: teori, konsep dan aplikasi," Jakarta: Salemba Empat, 2012.

[10] M. Mahmudi, "Manajemen Kinerja Sektor Publik," Akad. Manaj. Perusah. YKPN, Yogyakarta, 2005.

[11] Mardiasmo, Akutansi Sektor Publik. Yogyakarta: Andi, 2009.

[12] I. Ulum and H. Sofyani, "Akuntansi sektor publik," Univ. Muhammadiyah Malang Press. Malang, 2008

[13] S. Wasistiono, Pengelolaan Keuangan dan aset Daerah. Bandung: Fokus Media, 2010.

[14] J.-E. Lane, New public management. Taylor \& Francis US, 2000.

[15] A. F. Wijaya and O. R. Danar, Manajemen Publik: Teori dan Praktik. Universitas Brawijaya Press, 2014

[16] G. Tullock, "Entry barriers in politics," Am. Econ. Rev., vol. 55, no. 1/2, pp. 458-466, 1965.

[17] A. Downs, "Inside bureaucracy," 1967.

[18] W. A. Niskanen, Bureaucracy and representative government. Transaction Publishers, 1971.

[19] K. M. Eisenhardt, "Agency theory: An assessment and review," Acad. Manag. Rev., vol. 14, no. 1, pp. 57-74, 1989.

[20] S. A. Wahab, "Analisis kebijakan: dari formulasi ke penyusunan model-model implementasi kebijakan publik," Jakarta Bumi Aksara, vol. 77, 2012.

[21] B. Winarno, "Kebijakan publik: Teori dan proses," Yogyakarta Media Press., 2007.

[22] Mubyarto, Menuju Gerakan Nasional Penanggulangan Kemiskinan: Kajian Bersama Pengembangan Kebijaksanaan. Yogyakarta: Aditya Media, 1997.

[23] A. Heroepoetri, Peran Serta Masyarakat Dalam Pengelolaan Lingkungan. WALHI, 1993.

[24] A. Abe, Perencanaan daerah partisipatif. Pondok Edukasi, 2002. 